\title{
Rövid távú koraholocén (8200 év) klímafluktuációk vegetációra gyakorolt hatása a Déli-Kárpátok Retyezát-hegységében
}

\section{Pál Ilona $^{1^{*}}$ - Magyari Enikố ${ }^{1}$ - Finsinger Walter ${ }^{2}$ - Braun Mihály ${ }^{3}$ - Pálfy József ${ }^{1}-$ Molnár Mihály ${ }^{4}$ - Buczkó Krisztina ${ }^{5}$}

${ }^{1}$ ELTE TTK Általános és Alkalmazott Földtani Tanszék, 1117 Budapest Pázmány Péter stny. 1/C.

${ }^{2}$ Centre de Bio-Archeologie et d'Ecologie UMR 5059, Montpellier, France.

${ }^{3}$ Debreceni Egyetem Szervetlen és Analitikai Kémiai Tanszék, 4032 Debrecen, Egyetem tér 1. Pf. 21.

${ }^{4}$ MTA ATOMKI Hertelendi Ede Környezetanalitikai Laboratórium, 4001 Debrecen, Pf. 51.

${ }^{5}$ Magyar Természettudományi Múzeum, 1087 Budapest, Könyves Kálmán krt. 40.

*E-mail: palilona@caesar.elte.hu

\begin{tabular}{|c|c|}
\hline Absztrakt & 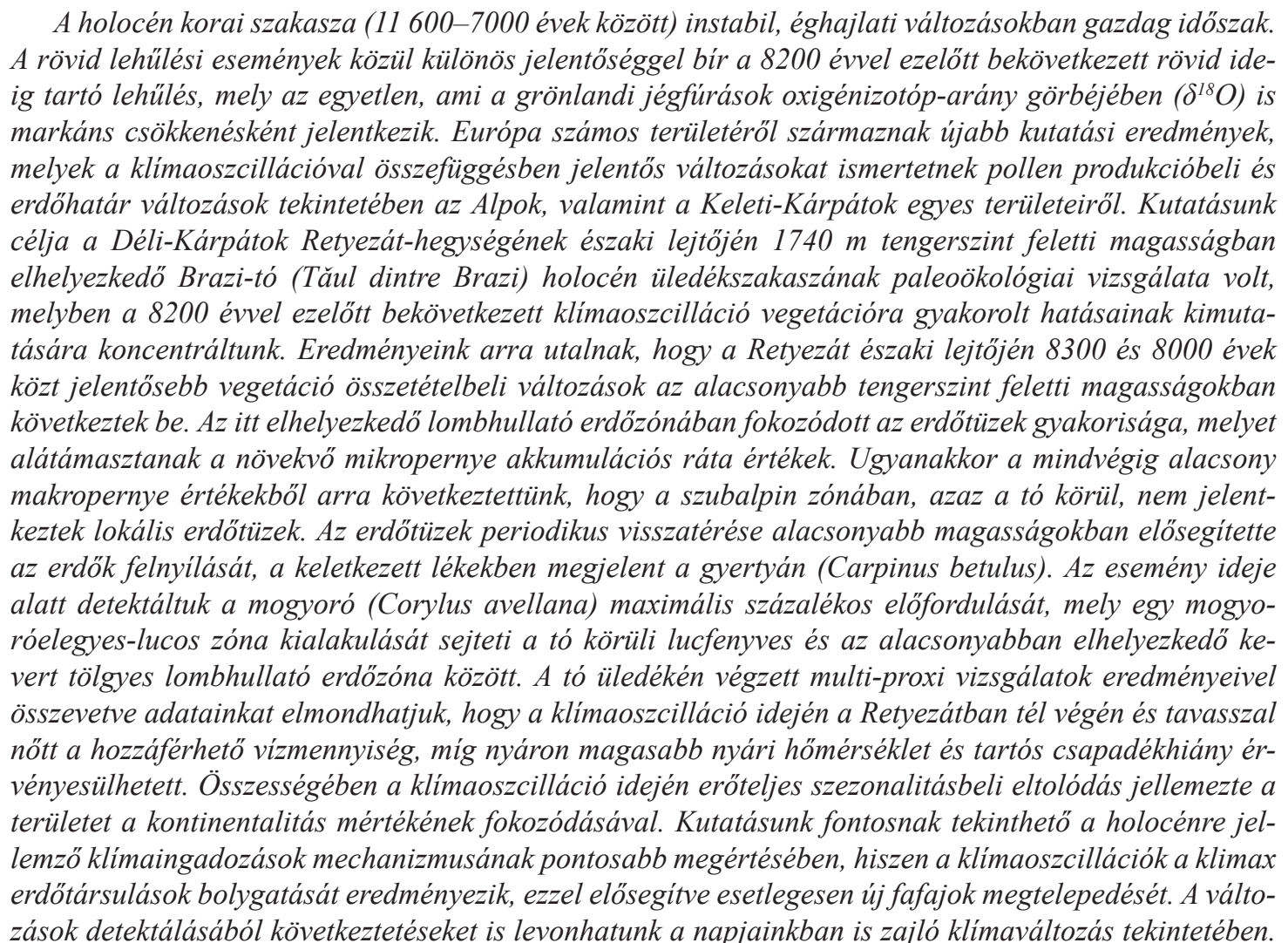 \\
\hline
\end{tabular}

Kulcsszavak pollenanalízis, mikropernye, diatóma, holocén, klímaoszcilláció, 8200 év

DOI: 10.17799/2014.2.13 


\section{Bevezetés}

A holocén a negyedidőszak utolsó interglaciális időszaka, amely kb. 11600 évtől tart napjainkig (Mayewski et al., 2004; Magny et al., 2007). A hirtelen bekövetkező és rendszerint 100-300 évet felölelő klímaingadozások (Stocker, 2000; Alley et al., 2003; Mayewski et al., 2004) az egész időszakra jellemzőek, azonban gyakoriságuk a holocén korai szakaszában, 11600 és 7000 évek közt megnövekszik (Magny et al., 2007). Középnyugat-Európa tavainak vizsgálati eredményeiből fontos információkat kaphatunk az egyes klímaváltozási események és a környezeti válaszreakciók kapcsolatáról (Haas, Richoz, Tinner, \& Wick, 1998; Tinner \& Lotter, 2001; Kofler, Krapf, Oberhuber, \& Bortenschlager, 2005; Joerin, Stocker, \& Schlüchter, 2006; Magny, 2007; Valsecchi, Carraro, Conedera, \& Tinner, 2010). Az eddigi és a folyamatban lévő kutatások állása szerint ezek a klímaváltozási események több tényező együttes változásainak a következményei, úgymint a naptevékenység változásai, beeső napsugárzás mértékének változásai, a légkörben nagyobb koncentrációban jelen lévő vulkáni aeroszolok és üvegházhatású gázok mennyisége, a jégborítás változásai, vagy éppen a növényzettel való borítottság mértéke (Mayewski, et al. 2004; Wanner et al., 2008; Weninger et al., 2009).

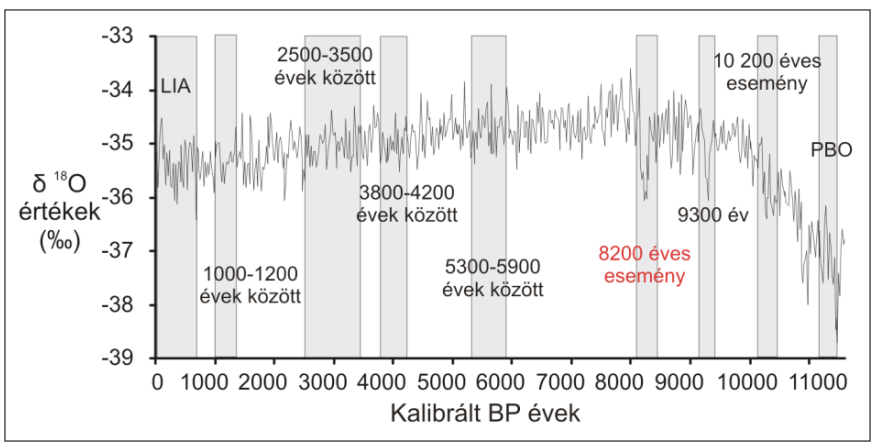

1. ábra: Az NGRIP $\delta^{18} \mathrm{O}$ értékeinek változása a holocén folyamán. A szürke sávok a holocén rövid ideig tartó klímafluktuációit lefedő idôszakait jelölik. Az ábrán látható rövidítések: LIA - Little Ice Age (Kis jégkorszak), PBO - Preboreal Oscillation (Preboreális Oszcilláció).

A rövid időszakot felölelő klímaingadozások közül különös jelentőséggel bír a 8200 évvel ezelőtt bekövetkezett klímaoszcilláció, mely a grönlandi jégfúrások oxigénizotóp-arány görbéjében (1.ábra) is markáns csökkenésként jelentkezik (Tinner \& Lotter, 2001; Vinther et al., 2006; Weninger et al., 2006; Rasmussen et al., 2006, Rasmussen, Vinther, Clausen, \& Andersen, 2007; Thomas et al., 2007; Young, Briner, Rood, \& Finnkel, 2012).

Az esemény kialakulásának oka lehetett, hogy kb. 8470 évvel ezelőtt nagy mennyiségü édesvíz ömlött az ÉszakAtlanti-óceán térségébe, mely az Agassiz-tó (Lake Agassiz) lecsapolódása miatt következhetett be (Barber et al., 1999; Teller, Leverington, \& Mann, 2002; Veski, Seppä, \& Ojala, 2004). Az Atlanti-óceán áramlási rendszere na- gyon érzékenyen reagál az édesvíz beáramlására (Renssen \& Isarin, 2001; Bauer, Ganopolski, \& Montoya, 2004), mely többek közt a Golf-áramlat változásain keresztül jelentősen befolyásolja Európa éghajlatát (Rahmstorf, 2000). A nagyobb mennyiségben beáramló édesvíz az áramlat átfordulási pontjának délebbre tolódását eredményezheti, mely a mélységi víz keletkezési intenzitásának csökkenésében nyilvánul meg. Következménye lehet a magasabb földrajzi szélességeken elhelyezkedő területek lehülése, vagy éppen nagyobb csapadékmennyiség elöfordulása Közép-Európa területein (2. ábra) a megerősödő ciklonikus tevékenység miatt (Magny, Bégeot, Guiot, Marguet, \& Billaud, 2003; Magny, 2007).

Ezzel a klímaváltozási eseménnyel valószínúleg össze-

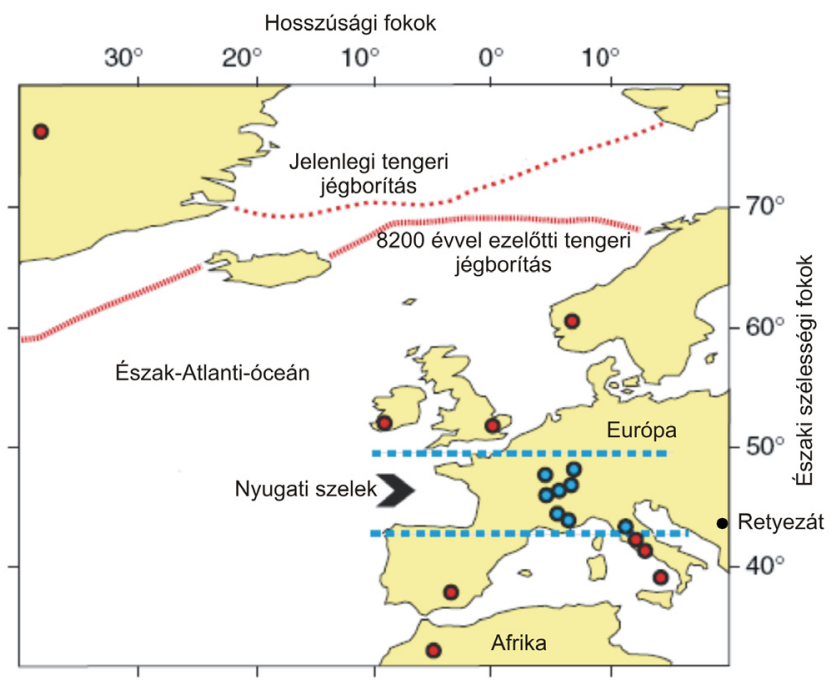

2. ábra: A 8200 éve történt klímaváltozás idején kimutatható éghajlati viszonyok Európában (Magny, 2007 alapján). A piros pontozás a jelenlegi tengeri jégborítás déli határát, míg a piros folytonos vonal a 8200 évvel ezelőtti tengeri jégborítás határát jelzi. A piros pontok azokat a tavakat jelölik, melyeknek az esemény ideje alatt csökkent a vízmélysége, míg a kék pontokkal jelölt tavaknál növekvô vízszint volt kimutatható. A fekete pont a mintavételi terület, a Retyezát-hegység elhelyezkedését szemlélteti.

függésbe hozható az Alpokban detektált pollenprodukcióban bekövetkező csökkenés és/vagy az erdőhatár változása 8200 év körül (Kofler et al., 2005; Tinner \& Lotter, 2001). A vegetáció összetételében bekövetkezett változásokat kimutathatjuk pollenanalízis segítségével (Peteet, 2000; Wick, 2000; Tinner \& Lotter, 2001; Ortu, Brewer, \& Peyron, 2006; Seppä, 2007), mely a magashegységi területeken regionális információt nyújt számunkra, hiszen ebben az esetben számolnunk kell a felszálló légáramlatok által szállított, alacsonyabb erdőövekből érkező pollenekkel is (Ortu et al., 2006; Ortu, David, \& Peyron, 2009). 


\section{Célkitúzés}

A vizsgált területünk a Déli-Kárpátok Retyezát-hegységében található. A hegységben kettős klímahatás érvényesül. Éghajlata télen a balkáni területek és a Fekete-tenger éghajlatával mutat hasonlóságot, tavasszal és nyáron leginkább a balkáni területekkel, míg összel a nyugati területekkel korrelál (Magyari et al., 2013). Elmondható tehát, hogy a Retyezát éghajlata leginkább a balkáni területekkel azonos tendenciákat mutat, ugyanakkor őszi időjárását a nyugati szelek befolyásolják. Ez a kettősség felveti azt a lehetőséget, hogy a klímaoszcilláció idején Európa éghajlati tagolódása nemcsak a földrajzi szélességek mentén rajzolódik ki, hanem a földrajzi hosszúságok mentén is. A Retyezátban bekövetkező vegetációbeli változások detektálása fontosnak tekinthető, hiszen rámutathatnak egyrészt arra, hogy az egyes klímaváltozási események milyen hatással vannak az Atlanti-óceántól távol eső, a kontinens belsejében elhelyezkedő területen (2. ábra). Másrészt pedig arra, hogy Magny (2007) eredményei alapján a kontinens középső részén érvényesülő csapadékosabb éghajlat kimutatható-e a kontinens belsejében elhelyezkedő területeken is, vagy indokolt-e egy földrajzi hosszúság menti választóvonal kijelölése.

\section{Módszerek}

\subsection{A mintaterület bemutatása}

A mintaterület a Retyezát-hegység északi lejtőjén (3. ábra), a Gales-völgy nyugati peremén elhelyezkedő Brazi-tó (Taŭl dintre Brazi). A tó az erdőhatár alatt, 1740 méter tengerszint feletti magasságban, a szubalpin övben helyezkedik el. Területe 0,4 ha, legnagyobb vízmélysége 1 méter körüli. A tavat kevert fenyőerdő veszi körül, melynek jellemző fajai a közönséges lucfenyő (Picea abies) és a havasi cirbolyafenyő (Pinus cembra). A tó partján úszó tôzegmohalápot találunk, ahol a tózegmoha fajok egybefüggő szőnyeget alkotnak a törpefenyővel (Pinus mugo) a cserjeszintben. A tó körül jelentős mennyiségben fordul elö még a vörös és fekete áfonya (Vaccinium vitis-ideae, V. myrtillus), az erdélyi rododendron (Rhododendron myrtifolium), a hüvelyes gyapjúsás (Eriophorum vaginatum), valamint a szálas szittyó (Juncus filiformis) (Magyari et al., 2009, 2012; Tóth et al., 2012).

\section{2. Üledékmintavétel és kor-mélység összefüg- gés}

A mintavétel 2007 augusztusában történt Livingstone-típusú dugattyús magmintavevővel (Magyari et al., 2009; Braun et al., 2013). Az üledék feldolgozása során elkészült az üledék rétegtani leírása (lásd részletesen Magyari et al., 2009), valamint a kinyert növényi makrofosszíliák

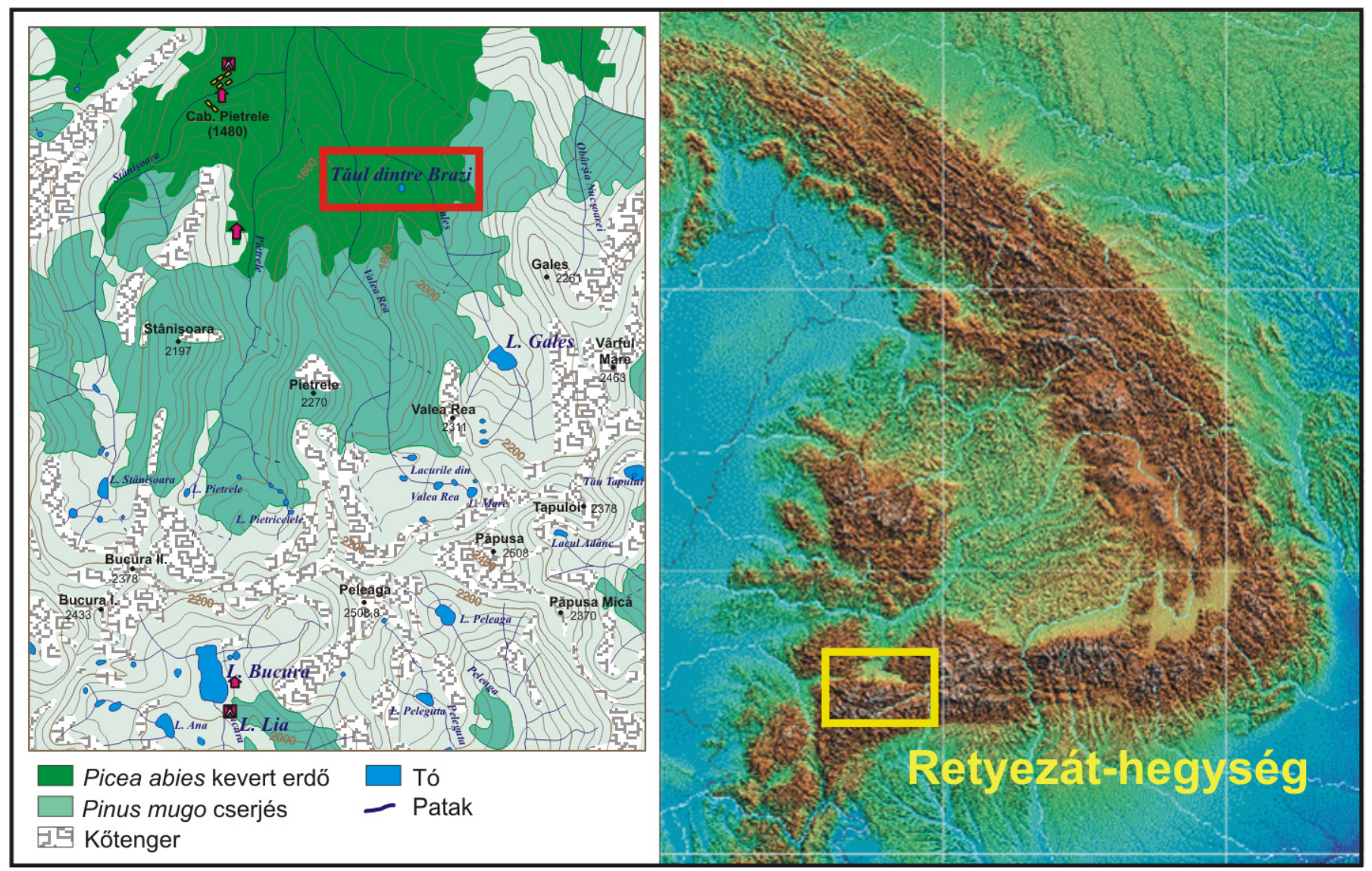

3. ábra: A Retyezát-hegység (sárga téglalappal jelölt) helyzete a Kárpátok íve mentén, valamint a Brazi-tó (piros téglalappal jelölt) elhelyezkedése a vizsgált hegységen belül. 
1.táblázat: A Brazi-tó 110 és 505 cm közöttiüledékszakaszánakradiokarbon adataiazadottmélységben talált makrofosszíliákalapján.

\begin{tabular}{|c|c|c|c|c|c|c|c|}
\hline Fúrás & $\begin{array}{l}\text { Laboratóriumi } \\
\text { kód }\end{array}$ & $\begin{array}{c}\text { Vizsgált } \\
\text { üledékkomponens }\end{array}$ & $\begin{array}{l}\text { Mélység } \\
\text { (cm) }\end{array}$ & $\begin{array}{l}{ }^{14} \text { C alapú } \\
\text { koradat } \\
\text { (év BP) }\end{array}$ & $\begin{array}{c}\text { Kalibrált } \\
\text { koradat } \\
\text { tartománya } \\
\text { (év BP) }\end{array}$ & $\begin{array}{c}\text { Középérték } \\
\text { hibákkal } \\
\text { (év BP) }\end{array}$ & Megjegyzés \\
\hline TDB-1 & Poz-26103 & Picea abies tülevelek & 119 & $725 \pm 30$ & $652-723$ & & idősebb \\
\hline TDB-1 & $\mathrm{I} / 338 / 1 \#$ & $\begin{array}{l}>180 \mu \mathrm{m} \text { frakció, növényi } \\
\text { makrofosszília }\end{array}$ & 127 & $375 \pm 25$ & $319-503$ & $411 \pm 92$ & \\
\hline TDB-1 & $\mathrm{I} / 338 / 2 \#$ & $\begin{array}{l}<180 \mu \mathrm{m} \text { frakció, } \\
\text { leginkább szervesanyag }\end{array}$ & 127 & $1018 \pm 23$ & $913-970$ & & kihagyott \\
\hline TDB-1 & $\mathrm{I} / 338 / 2 \#$ & $\begin{array}{c}<180 \mu \mathrm{m} \text { frakció, } \\
\text { leginkább szervesanyag }\end{array}$ & 127 & $1031 \pm 23$ & $921-975$ & & kihagyott \\
\hline TDB-1 & Poz-26104 & Pinus mugo tobozpikkely & 160 & $1735 \pm 30$ & $1562-1712$ & $1637 \pm 75$ & \\
\hline TDB-1 & I/338/3\# & Pinus gally & 204 & $2611 \pm 23$ & $2724-2763$ & $2743,5 \pm 19,5$ & \\
\hline TDB-1 & Poz-206106 & Pinus mugo toboz & 238 & $3045 \pm 30$ & $3205-3356$ & $3280,5 \pm 75,5$ & \\
\hline TDB-1 & $\mathrm{I} / 338 / 4 \#$ & $\begin{array}{l}>180 \mu \mathrm{m} \text { frakció, növényi } \\
\text { makrofosszília }\end{array}$ & 280 & $3962 \pm 30$ & $4381-4520$ & & kihagyott \\
\hline TDB-1 & $\mathrm{I} / 338 / 5 \#$ & $\begin{array}{l}>180 \mu \mathrm{m} \text { frakció, } \\
\text { leginkább szervesanyag }\end{array}$ & 280 & $3987 \pm 26$ & $4416-4521$ & $4468,5 \pm 52,5$ & \\
\hline TDB-1 & Poz-26107 & Pinus gally & 315 & $5040 \pm 40$ & $5708-5902$ & $5805 \pm 97$ & \\
\hline TDB-1 & Poz-26108 & Picea abies tülevelek & 355 & $6320 \pm 40$ & $7163-7324$ & $7243,5 \pm 80,5$ & \\
\hline TDB-1 & $\mathrm{I} / 338 / 6 \#$ & $\begin{array}{l}>180 \mu \mathrm{m} \text { frakció, növényi } \\
\text { makrofosszília }\end{array}$ & 391 & $6925 \pm 30$ & $7683-7828$ & $7755,5 \pm 72,5$ & \\
\hline TDB-1 & Poz-26109 & Picea abies tülevelek & 393 & $6130 \pm 40$ & $6926-7160$ & & fiatalabb \\
\hline TDB-1 & Poz-26110 & $\begin{array}{l}\text { Picea abies túlevelek és } \\
\text { magok }\end{array}$ & 450 & $8240 \pm 50$ & $9072-9326$ & $9199 \pm 127$ & \\
\hline TDB-1 & Poz-26111 & Picea abies tülevelek & 505 & $8810 \pm 50$ & $9670-10155$ & $9912,5 \pm 245,5$ & \\
\hline TDB-1 & Poz-31714 & Pinus mugo tülevelek & 521 & $9150 \pm 50$ & $10226-10433$ & $10329,5 \pm 103,5$ & \\
\hline TDB-1 & Poz-26112 & Picea abies toboz & 545 & $9610 \pm 50$ & $10766-11167$ & $10966,5 \pm 200,5$ & \\
\hline TDB-1 & Poz-31715 & Pinus mugo tülevelek & 557 & $9980 \pm 100$ & $11216-11826$ & $11521 \pm 305$ & \\
\hline TDB-1 & Poz-31716 & Pernye & 569 & $10870 \pm 70$ & $12598-12925$ & $12761,5 \pm 163,5$ & \\
\hline TDB-1 & Poz-27305 & Pinus sp. tülevelek (2) & 578 & $11590 \pm 60$ & $13287-13620$ & $13453,5 \pm 166,5$ & \\
\hline TDB-1 & Poz-26113 & Picea abies tobozpikkely & 591 & $9690 \pm 50$ & $11067-11225$ & & fiatalabb \\
\hline
\end{tabular}

alapján AMS ${ }^{14} \mathrm{C}$ kormeghatározás készült (Wohlfarth et al., 2001; Walker, 2005). 21 koradat áll rendelkezésünkre, melyet az 1. táblázatban összesítettünk, ahol a szürke színezéssel ellátott adatokat a kormodellező program outlier-ként ismerte fel, mert vagy túl fiatalnak, vagy túl idősnek bizonyultak. A holocén üledékszakaszra 10 koradat felhasználásával a CLAM programban készítettünk kormodellt a „smooth spline” görbeillesztési eljárást alkalmazva (Finsinger, Kelly, Fevre, \& Magyari, 2014). Az üledék alsóbb szakaszára (505-600 cm közt) a meglévő 5 radiokarbon koradat birtokában már korábban elkészült a kormodell (Magyari et al., 2009, 2012). Ezeket a táblázatban világossárga színezéssel jelöltük.

\subsection{Pollenanalízis és adatelemzés}

Az üledék teljes szakaszán, négy cm-es felbontásban pollenanalízist végeztünk, azonban a jelen tanulmányban csak az üledék 387 és 414 cm-e közötti szakaszát mutatjuk be, mely a korábban ismertetett klímaoszcilláció idejét fedi le (kb. 7795-8325 évek közt). E szakaszon a korábbi négy $\mathrm{cm}$-es felbontást további 16 minta előkészí- tésével centiméteres felbontásra növeltük. A mintákon a sztenderd pollen analitikai feltárás lépéseit alkalmaztuk (Bennett \& Willis, 2001), melyhez minden centiméterböl egy-egy $\mathrm{cm}^{3}$-nyi mintát használtunk fel. A feltárás során Lycopodium tablettát adtunk az üledékmintákhoz, melyeket a pollenlemezeken szintén megszámoltunk. A pollen koncentrációk kiszámolásához szükségünk van az egy $\mathrm{cm}^{3}$-ben található Lycopodium koncentrációjára, melynek kiszámolásához szükséges egy Lycopodium tabletta ismert spóraszáma, ami jelen esetben $18584 \mathrm{db} \pm 7,4 \%$ ( \pm 1378 db) spóra (Maher, 1981 alapján), a feltárás során az egy $\mathrm{cm}^{3}$-nyi üledékhez adott tabletta száma, valamint az üledék akkumulációs rátája. Adott faj pollen koncentrációjának megadásához az egy $\mathrm{cm}^{3}$ térfogatú üledékben található Lycopodium koncentrációt meg kell szorozni az adott tárgylemezen számolt taxon értékeivel, majd az adott mélységben számolt Lycopodiummal kell súlyozni. Mintánként legkevesebb 500 db szárazföldi pollent számoltunk és határoztunk meg. Fontos megjegyeznünk, hogy a Diploxylon típusú fenyőket törpefenyőként ( $P i$ nus mugo) azonosítottuk, mivel a területen a szintén ebbe 
a csoportba tartozó erdeifenyő (Pinus sylvestris) nem fordul elő. A kiszámolt pollenkoncentrációk és az üledék akkumulációs rátájának felhasználásával kiszámoltuk a pollen akkumulációs rátákat. A kapott érték kifejezi, hogy egy év alatt, egy négyzetcentiméternyi üledékfelületre mennyi pollen hullott. Ez az érték összefüggésben áll egy adott taxon populációméretével a Retyezát-hegység északi lejtőjén. Az eredmények jobb értelmezhetösége érdekében a százalékos pollendiagramot több szignifikáns zónára osztottuk fel adatelemzési program használatával (Bennett, 2007). A program megadott számú zónára osztja fel a diagramot a mennyiségi változások figyelembe vételével. A zónára bontásnál az információ tartalom alapján történő optimális felosztást használtuk, melynek elvét Birks és Gordon (1985) tanulmánya foglalja össze. Az egyes pollenzónák meghatározásánál csak azon terresztris növényfajok lettek figyelembe véve, melyek összesítetten elérték, vagy meghaladták az 5\%-os relatív gyakoriságot legalább egy mintában.

A pollenszemekkel együtt meghatároztuk az üledékben az algákat, spórákat, mikropernye részecskéket és tülevél sztómákat (gázcsere-nyílások) is. Ahhoz, hogy átfogó képet kapjunk a pollenanalízis eredményeit összehasonlítottuk az üledéken végzett további vizsgálatok eredményeivel (diatóma, biogén kova, valamint szervesanyagtartalom analízis).

\subsection{További vizsgálati módszerek}

Az üledék teljes szakaszán diatóma és izzítási veszteség elemzést végeztünk egy-négy cm-es felbontásban, hogy információt kaphassunk a tavi ökoszisztéma és a szervesanyag-tartalom változásairól. A biogén kova elemzést négy $\mathrm{cm}$-es felbontásban végeztük el. További módszertani részletek Buczkó et al. (2012), Buczkó, Magyari, Braun és Bálint (2013) és Magyari et al. (2013) munkájában olvashatóak.

\section{Eredmények}

\subsection{A pollenzónák általános bemutatása}

A Brazi-tó pollendiagramját nyolc pollen együttes zónára osztottuk fel (B-4 - B-11), melyek közül három pollenzóna összetételbeli változásait mutatjuk be, mely megelözi (B-6), magában foglalja (B-7) és követi (B-8) a 8200 évvel ezelőtt bekövetkezett klímaoszcillációt (4. ábra). A zónákat az idősebbtől a fiatalabb irányába tárgyaljuk.

\subsubsection{B-6 zóna, 530-436 cm, $10450-8870$ évek közt}

A pollenzónára jellemző a fásszárúak dominanciája (átlagosan 91\%). Ebböl a fák aránya átlagosan $66 \%$, a cserjéké pedig $25 \%$. Közel megegyező magas százalékban található meg a törpefenyő (Pinus subgenus Diploxylon) és a lucfenyő (Picea abies) pollenje a zóna ele-

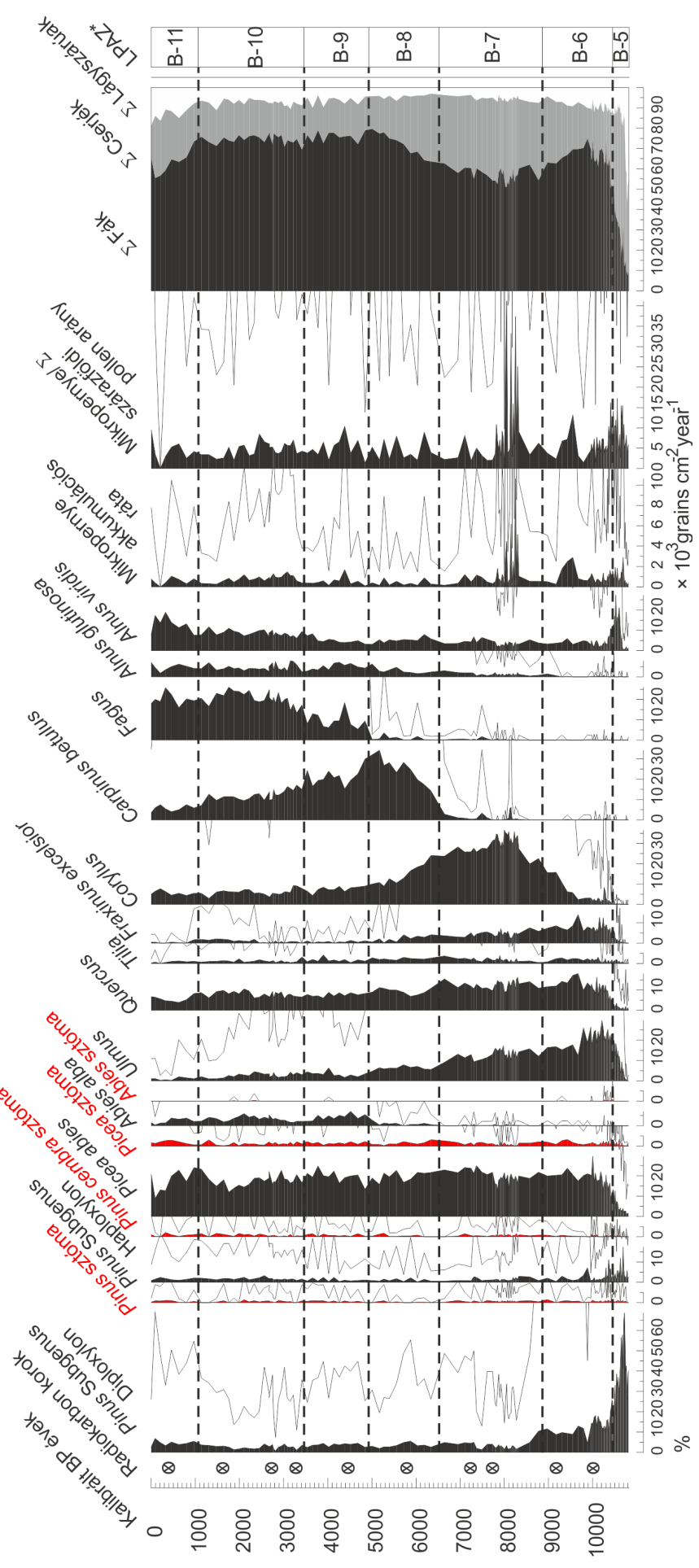

4. ábra: A Brazi-tó zónákra osztott holocén pollendiagramja kalibrált BP időskála mentén.

jén. 10000 év körül a lucfenyő százalékos értéke eléri a maximumot (29\%). A tó körüli jelenlétét alátámasztják a sztóma adataink (4. ábra - piros színezés), melyekből kiderül, hogy a lucfenyő mellett, jelen volt a törpe- és cirbolyafenyő (Pinus subgenus Haploxylon), valamint szálanként előfordult a jegenyefenyő (Abies alba) is. Az üledékben nagy mennyiségben vannak jelen a lombhullató taxonok pollenjei. A zóna elején nagy relatív gyakoriságban fordul elő a szil (Ulmus) pollenje (22\%), mely a zóna végére csökken (12\%). A tölgy (Quercus) értéke a zóna egészében közel azonos, 10\% körüli. A zóna 
elején megfigyelhetö a magas kőris (Fraxinus excelsior) és a havasi éger (Alnus viridis) közel azonos százalékban (4\%), mely a kőris esetében a zóna végéig, kisebb ingadozásokkal, de állandónak tekinthető. Ezzel szemben a havasi éger pollenjének százalékos elöfordulása fokozatos csökkenést mutat a zóna teteje felé haladva. Kis mennyiségben elöfordulnak más cserjék pollenjei is, mint pl. a mogyoróé (Corylus) és a törpe nyíré (Betula nana). 9690 év körül a mogyoró százalékának nagyarányú emelkedése figyelhető meg, mely 8775 évnél eléri a 23\%-ot. Néhány lágyszárú pollen is előfordul a zónában (52 taxon), összes százalékos értékük (NAP) mindössze átlagosan 9\%. A lágyszárú taxonok közül jellemzőek a pázsitfüfélék (Poaceae), a varjúháj (Sedum) és az üröm (Artemisia).

A zóna pollen- és sztómaösszetétele alapján elmondható, hogy a tó körül kezdetben nagyobb számban fordult elő a törpefenyő, mely később visszaszorult, és helyét részben átvette a lucfenyő. Alacsonyabban kontinentális kevert tölgyes lombhullató erdőket (Quercus-Fraxinus excelsior-Tilia-Ulmus) rekonstruálhatunk a pollenösszetétel alapján, mely hasonlóságot mutat a Keleti-Kárpátok egyidős vegetációjával, és ezen kevert tölgyesek modern analógjai ma az Urál hegységben fordulnak elő (Feurdean et al., 2008; Chytrý et al., 2010). A zóna végére összességében megfigyelhető kevert tölgyes domináns fajainak csökkenése, mely összefüggésbe hozható a mogyoró terjedésével. A Retyezát lombhullató erdeiben a szil fajok domináns szerepet tölthettek be a lombkorona összetételében. Feltételezhető, hogy a szil dominanciájú erdőkben a mogyoró vette át a lombkoronában a domináns szerepet, és különálló zónát képezett a tölgy-kőris erdők fölött. A mogyoró terjedése számos más kárpáti pollendiagramban is megfigyelhetö ebben az időszakban (Feurdean, 2005; Magyari et al., 2009; Tanțău, Feurdean, de Beaulieu, Reille, \& Fărcaş, 2011), mely nagy valószínüséggel a makroklíma változásával hozható összefüggésbe. Diagramunkban a 9550 év körül jelentkező nagyobb pernyecsúcsot követően a mogyoró növekvő pollenszázaléka figyelhető meg, így pozitív korreláció figyelhető meg a mogyoró terjedése és az erdőégések között, melyet korábban az Alpokban is észleltek (Finsinger, Tinner, van der Knaap, \& Ammann, 2006).

\subsubsection{B-7 zóna, 436-334cm, 8870-6520 évek közt}

A pollenzónát ismételten a fásszárúak dominanciája jellemzi (átlagosan 95\%), melyből a fák átlagosan 57\%-ot, míg a cserjék 38\%-ot képviselnek. A pollen- és sztómaösszetételi adatok alapján a tó körüli vegetációt továbbra is döntően a lucfenyő alkotta. A törpefenyő kezdeti 10\%-os előfordulása jelentősen csökken 8700 és 8600 évek közt. A mogyoró pollenje 8000 évnél éri el a legnagyobb százalékos értéket (36\%), melyet követően ( 7800 év után) megfigyelhető arányának fokozatos csökkenése.
Az alacsonyabb tengerszint feletti magasságból származó lombhullató erdőzóna kulcsfontosságú fajai (tölgy, magas kőris, szil) továbbra is magasa arányban vannak jelen. A lágyszárúak csekély mennyiségben (5\%) találhatóak meg (44 taxon), melyböl továbbra is a pázsitfüfélék, a varjúháj és az üröm jelenléte érdemel említést. A zónára jellemzőek az egyik mintáról a másikra jelentkező mikropernye csúcsok, melyek a diagram holocén szakaszán itt a legszembeötlöbbek.

A pollenösszetétel alapján 8600 és 7250 évek közt a kevert tölgyes és a lucfenyves zóna stabilizálódására következtethetünk. Közöttük mogyoró-elegyes lucfenyves erdők alakultak ki a Retyezát északi lejtőin, hasonlóan a Keleti-Kárpátok más vonulataival ebben az időszakban (Feurdean, 2005; Feurdean, Klotz, Mosbrugger, \& Wohlfarth, 2008; Tanţău et al., 2011). A mogyoró nagyobb százalékos aránya a nagyobb pollenprodukcióval is összefüggésbe hozható, melyet a mogyoró abban az esetben produkál, ha nyílt lombkorona fó alkotójaként van jelen (Andersen, 1967).

\subsubsection{B-8 zóna, 334-291cm, 6520-4920 évek közt}

A zónára továbbra is a fásszárúak dominanciája jellemző (átlagosan 96\%). Ebből a fák átlagosan 72\%-ot, míg a cserjék átlagosan 24\%-ot képviselnek. A lucfenyő és a törpefenyő százalékos aránya változatlan marad ebben a zónában, amiből a tó körüli lucos összetételének változatlanságára következtehetünk. Az alacsonyabb tengerszint feletti magasságból származó fásszárú pollenek arányaiban jelentős változás figyelhető meg ebben a zónában. A zárt erdőséget alkotó tölgy-kőris-szil pollenszázalékai egyaránt csökkenést mutatnak. A 6640 évtől kezdődő és a 4845 évig tartó nagyarányú csökkenés leginkább a tölgy esetében mutatkozik meg (15\%-ról 8\%-ra). A mogyoró pollenszázalékéban is jelentős csökkenés figyelhető meg (24\%-ró1 9\%-ra), míg a gyertyán (Carpinus betulus) kezdeti 14\%-os előfordulása a zóna végére a duplájára emelkedik (30\%). Legnagyobb százalékos előfordulását 5170 évnél éri el (34\%). Ezt követően folyamatosan megtalálható, hol alacsonyabb, hol pedig magasabb arányban a tó üledékében. 4845 évtől kezdődően a bükk (Fagus) fokozatos emelkedése figyelhető meg (9\%), melyböl első jelentősebb expanziójára következtethetünk a hegység északi lejtőjén. A lágyszárúak továbbra is alacsony számban (átlagosan 4\%) találhatóak meg (28 taxon) a zónában, leginkább a pázsitfúfélék és az üröm által reprezentálva.

A pollenösszetétel alapján a tó körül stabil lucfenyves és törpefenyves állományt feltételezhetünk 6520-4920 évek közt. Alacsonyabban a mogyoró pollenjének csökkenése és a gyertyán emelkedése arra utal, hogy a kevert tölgyes és a lucos zóna közé ékelődő mogyoróelegyes lucosokat gyertyán dominanciájú erdők váltották fel, a lucfenyő állományai pedig a pollen akkumulációs ráta 


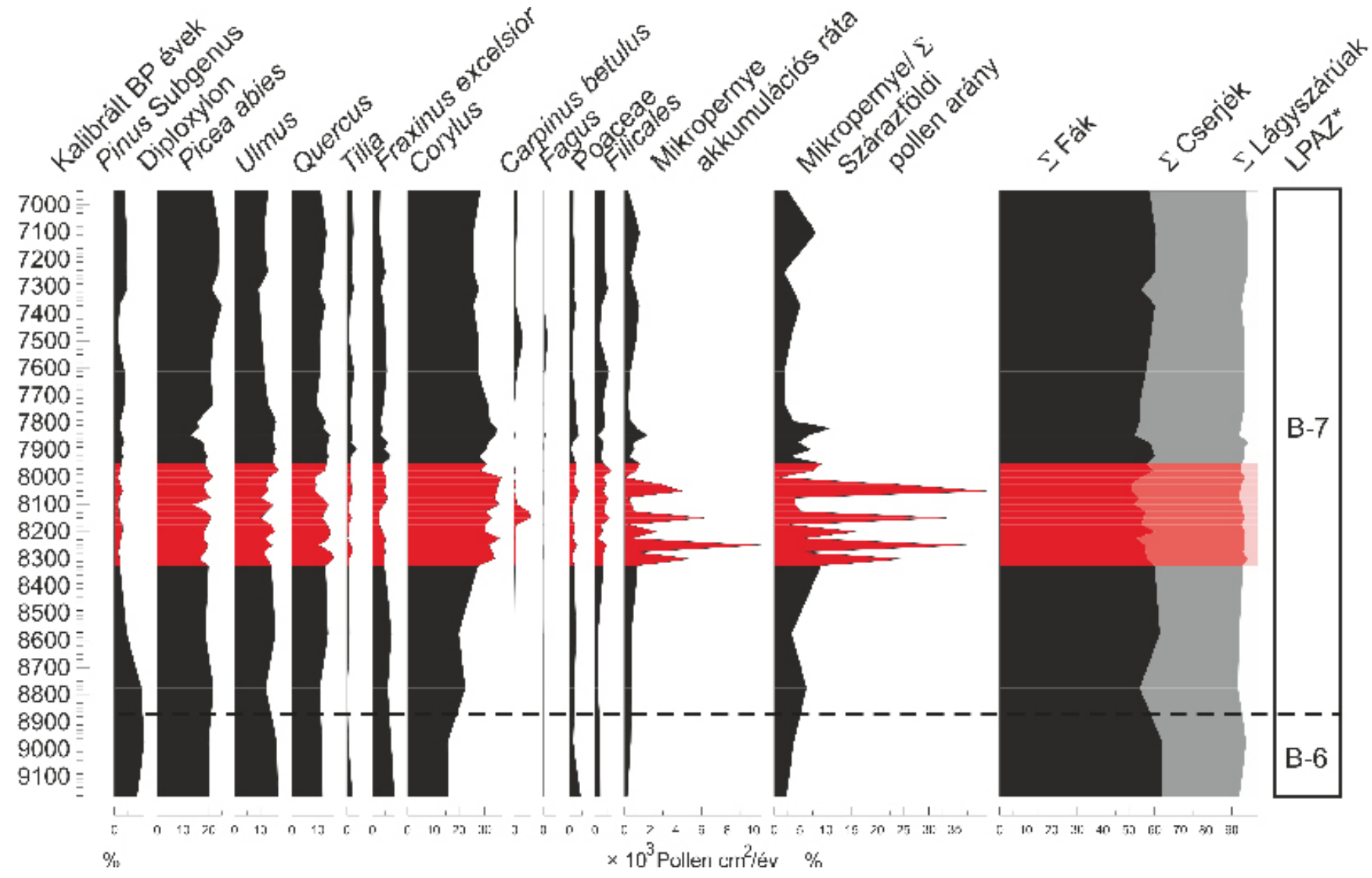

5. ábra: A 8200 éves klímaoszcilláció idején történő pollen és mikropernye tartalombeli változások a Brazi-tóban. A diagram 6950 és 9170 évek között a jellemző taxonokat mutatja. A piros sávval jelzett szakaszban figyelhetőek meg azok a változások, melyek összefüggésbe hozhatók a klímaoszcillációval.

értékek alapján feltehetően csökkentek (Magyari et al., 2011). A vezetö szerepet a korábban csak alacsony arányban jelen lévő gyertyán vette át, mely a korábbi kisebb társulásból sikeresen kolonizált.

\subsection{A klímaoszcilláció hatása a növényzet összetételére}

A 8200 évvel ezelött bekövetkezett klímaoszcillációval összefüggésbe hozható néhány jelentős pollen-összetételbeli és mennyiségi változás, melyek a lombhullató fajokat érintik. A változások részletesebb elemzése érdekében külön ábrákon tüntettük fel a pollendiagram 6950 és 9170 évek közti szakaszának százalékos (5. ábra) és akkumulációs ráta értékekeit (6. ábra).

A tó körül található fajok pollenszázalékaiban jelentösebb változás nem tapasztalható a 8200 éves klímaoszcillációt felölelő időszakban. A tó körüli fajok a lucfenyő, a cirbolyafenyő, a törpefenyő, és a jegenyefenyő. Lokális jelenlétükre a növényi makrofosszília és sztóma vizsgálati eredmények utalnak (Magyari, Peyron, Tóth, Heiri, \& Lotter, 2012). Alacsonyabban kevert tölgyes lombhullató erdőzónát feltételezünk, melynek jellemző fajai a tölgy, magas kőris, szil és hárs. A legnagyobb változás 8900 év körül következett be, amikor a mogyoró eléri maximális százalékos előfordulását, egy a lombhullató és a lucfenyves erdőzóna közé ékelődő zónát képezve.
Ezt követően 8300 és 8100 évek közt ismétlődve megnövekszik a mikropernye akkumulációs értéke, melyek epizodikus erdötüzekre utalnak az alacsonyabb tengerszint feletti magasságokban elhelyezkedő kevert tölgyes lombhullató erdőzónában. A gyertyán pollen százalékának hirtelen megnövekedett aránya 8150 évvel ezelött egybeesik a harmadik mikropernye csúccsal. Megjelenése és pollenszázalékainak első emelkedése pedig egybeesik a mikropernye akkumulációs ráták kezdeti növekedésével ebben az időszakban, 8300 évvel ezelőtt. A 6\%-ot elérő gyertyán pollen értékek egyedülállónak tekinthetők ebben az időszakban a többnyire közel 1\%os előfordulások között. Hirtelen megjelenését összefüggésbe hozhatjuk a mogyoró (Corylus) és a magas kőris (Fraxinus excelsior) arányának átmeneti csökkenésével. A mogyoró tekintetében kisebb fokú csökkenés látható, nem úgy, mint a magas kőris esetében. A mogyoró százalékos aránya 8250 évig fokozatos emelkedést, majd ezt követően kisebb csökkenést mutat, végül visszatér a zavarást megelőző állapotába. A magas kőris ezzel szemben az üledékben kisebb arányban található meg, és az ábrázolt időszakban kisebb fokú százalékos csökkenése figyelhető meg. 8250 év után százalékos aránya szintén lecsökken, majd visszatér eredeti állapotába. 
Ahhoz, hogy egyértelmüen eldönthessük, melyik taxon csökkenése kapcsolható össze a gyertyán arányának növekedésével, meg kell vizsgálnunk a pollen akkumulációs rátákban bekövetkező változásokat (6. ábra).

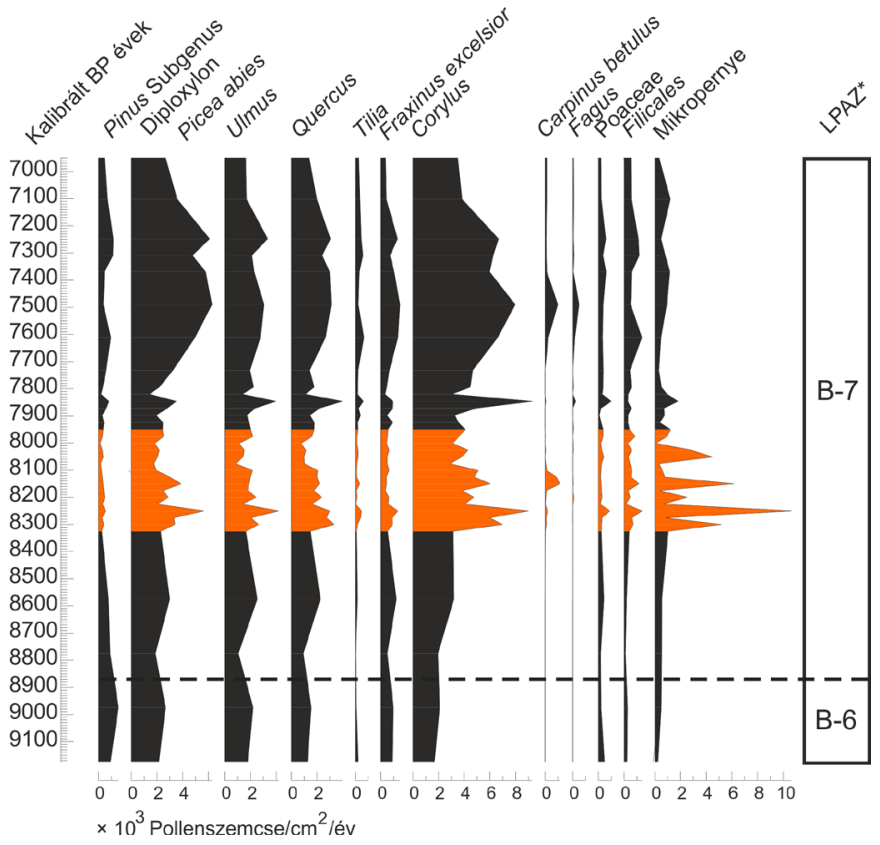

6. ábra: A pollen akkumulációs ráták 6950 és 9170 évek között. A narancssárga színnel jelölt szakasz a 8200 év körüli pollen akkumulációs rátaértékeket emeli ki.

Az ábrán csak azokat a taxonokat tüntettük fel, melyek jelentős arányban megtalálhatóak a tó körül, illetve alacsonyabb tengerszint feletti magasságban. Az ábrán egyértelmüen látható, hogy mikor a gyertyán akkumulációs rátája növekszik, a mogyoróéban is növekedés tapasztalható (8150 évnél). Ugyanekkor a magas kőris pollen akkumulációs rátájában kisebb fokú csökkenést tapasztalunk. Ebböl arra következtethetünk, hogy a gyertyán terjedése nem a mogyoró dominanciájú erdőkben és/vagy nem a mogyorót felváltva történt. Ahhoz, hogy alátámasszuk azt a feltételezésünket, miszerint a magas kőrisben bekövetkező csökkenés kapcsolatba hozható a gyertyán terjedésével, még jobban ráfókuszáltunk a 8000 és 8500 évek közti szakaszra. A 7. ábra a fontosabb taxonok pollenszázalékát és pollen akkumulációs rátáját mutatja be. Ezen az ábrán megfigyelhető a százalékos polleneloszlásokból, hogy a gyertyán a magas kőris rovására terjedt 8100 és 8180 évek között.

A klímaoszcillációval egy időben többször bekövetkező, nagy akkumulációs rátájú mikropernye csúcsokat detektáltunk, melyek a holocénre általában véve nem jellemzőek. Összesen öt epizodikus pernyecsúcs különíthető el. Az első 8300 évvel ezelött következett be, majd ezt követően további csúcsokat detektáltunk 8250 , 8200, 8150, valamint 8050 évvel ezelött. Az ábráról az is leolvasható, hogy a mikropernye periodikus megjelenése átmeneti csökkenést eredményezett az alacsonyabb területek kevert tölgyes lombhullató erdők fás pollenje-
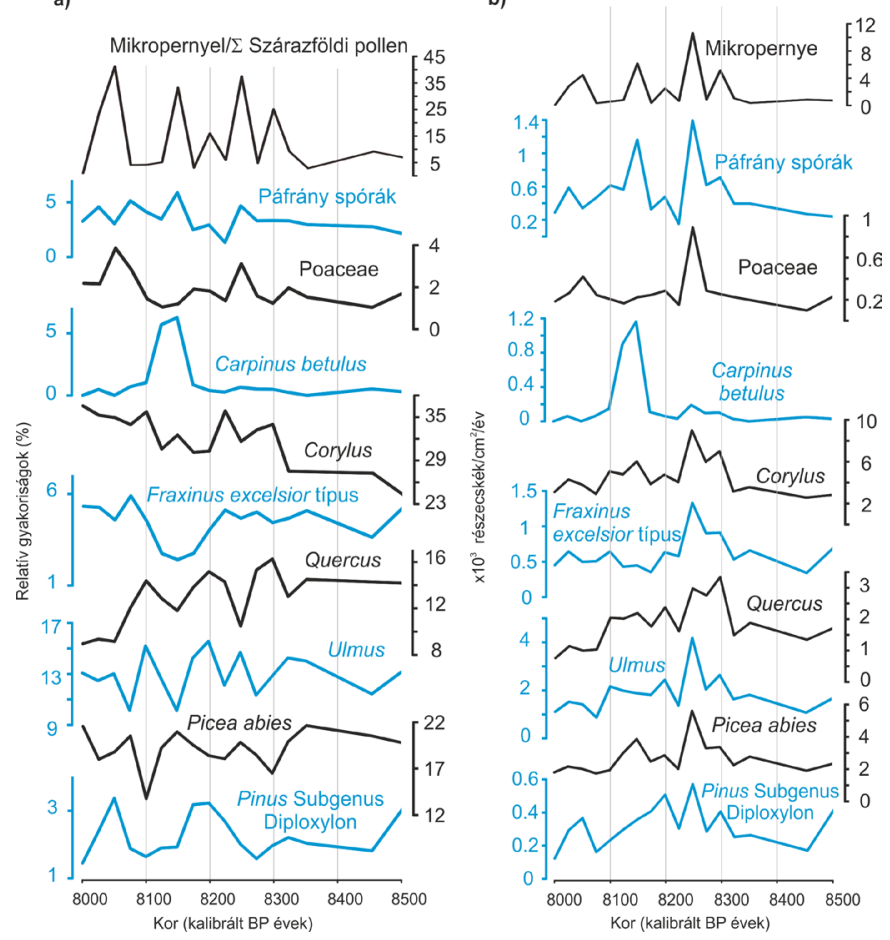

7. ábra: 8000 és 8500 évek közötti változások a pollen százalékos értékekben (a) és a pollen akkumulációs rátákban (b).

inek százalékaiban és esetenként a pollen akkumulációs rátáikban. Fontos megjegyeznünk, hogy a pernyecsúcsok nem minden esetben vontak maguk után pollen akkumulációs ráta csökkenést. A 8200 évvel ezelött bekövetezett klímaoszcilláció során jelentkező pernyecsúcsokra több taxon is egyértelmủ reakciót mutat (7. ábra). Az első nagyobb pernyecsúcsra a páfrányok (Filicales) és a füfélék (Poaceae) reagálnak azonnal, ahol előbbi megnövekedett aránya az erdőtüzek utáni korai szukcesszióra utalhat. Jól megfigyelhető azonban, hogy a gyertyán csak a harmadik pernyecsúcsot követően jelenik meg nagyobb arányban. A gyertyán esetében ezt egy késleltetett válaszként értelmezhetjük, mely nagy valószínüséggel összefüggésbe hozható az erdőtüzek hatására kialakuló lombkorona lékekkel, melyekben a gyertyán 8150 évnél sikeresen kolonizált és vett részt a szekunder szukcesszióban. 8200 év körül a tó körüli vegetáció összetételében nem történt számottevő változás. Arányuk az üledékben közel azonosnak tekinthető.

\subsection{A pollen adatok értékelése}

Eredményeink alapján elmondhatjuk, hogy a Retyezáthegység északi lejtőjén a 8200 évvel ezelőtt jelentős változások érzékelhetőek a tavi üledékben talált jellemző fafajok tekintetében. A 8. ábrán sematikusan bemutatjuk a Retyezát-hegység északi lejtőjének feltételezett növényzeti zonációját a klímaoszcillációt övező időszakban. A vizsgálatunk alapját képező Brazi-tó 1740 m tengerszint feletti magasságban, az erdőhatár alatt a szubalpin övezetben helyezkedik el. 


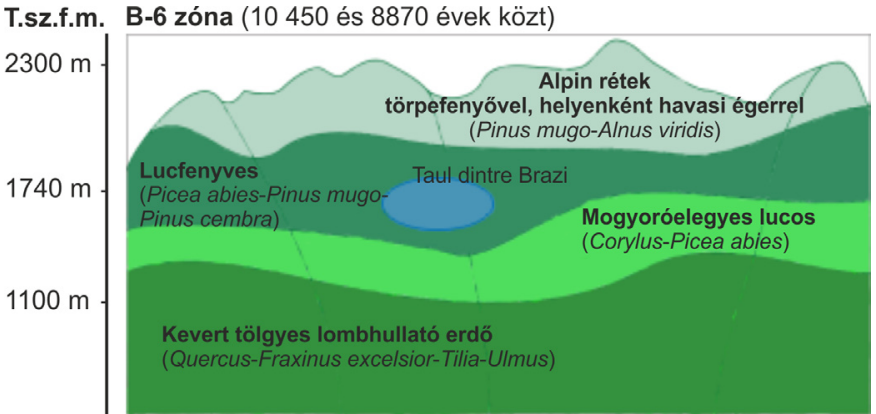

8. ábra: A Brazi-tó elhelyezkedése és az üledékének vizsgálata alapján feltételezett erdőösszetétel.

A tó körül lucfenyő és törpefenyő alkotta társulást feltételezhetünk a sztóma és pollen vizsgálatok alapján. A törpefenyő már ekkor is feltehetően a tóparti láphoz kötődik, zonálisan az erdőhatár fölött fordul elő nagyobb állományokban. Alacsonyabb tengerszint feletti magasságban kevert tölgyes lombhullató erdőket találunk, melynek jellemző fajai a tölgy, a szil, a magas kőris, valamint a hárs lehettek. A vizsgált időszakban eredményeink alapján feltehetően a lucos és tölgyes zóna közé ékelődő mogyoró zónát mutathatunk ki a klímaoszcillációt magában foglaló időszak alatt a tó üledékében jelentősen megnövekedő mogyoró pollenjei alapján. Az Alpokban végzett kutatás eredménye alapján elmondható, hogy a mogyoró a mainál hidegebb telek, ugyanakkor száraz és meleg nyarak során tudott megtelepedni az Alpok lejtőin a kora holocén (10 400 évvel ezelőtt) folyamán (Finsinger et al., 2006). A tölgy és a mogyoró csak kis mértékben elegyedett egymással, mert kis különbséggel ugyan, de más feltételekhez adaptálódtak, mert a tölgy nyári középhőmérséklet-igénye magasabb a mogyoróénál. A mogyoró tágabb tűrésủ a nyári hőmérsékletre és a szárazságra, valamint a regeneratív potenciálja az erdőtüzeket követően jobb a tölgynél (Finsinger et al., 2006). A Keleti-Kárpátok északnyugati oldalán található Gutin-hegység egy $730 \mathrm{~m}$ tengerszint feletti magasságban elhelyezkedő krátertó üledékének vizsgálatából arra következtettek, hogy 10750 évvel ezelött a tölgy, a hárs és a magas kőris terjedt el, majd ezt követően 10200 évvel ezelőtt a mogyoró terjedése indult meg (Feurdean, 2005), 9300 és 5750 évek között vált dominánssá, 9300 évnél érte el legmagasabb pollenszázalékát (Feurdean, 2005). A mi esetünkben a mogyoró dominanciája 9690 és 7800 évek közé tehetö, maximális pollenszázalékát pedig 8000 évvel ezelött érte el a Retyezát-hegység északi lejtöjén. Összehasonlítva a két területet, azt mondhatjuk, hogy a mogyoró expanziója a Retyezátban kb. 200 évvel hamarabb következik be, mint a Gutin-hegységben, és dominanciája korábban ér véget a Retyezát szubalpin övből származó diagramjában. Ez abból is adódhat, hogy a Gutin-hegység tava belehelyeződik a középső holocén mogyoróelegyes lucfenyves zónájába, így mindaddig magas mogyoró százalékokat mutat, amíg a mogyoró ott jelen van. Továbbá a gyertyán szerepe alárendeltebb a Gu-

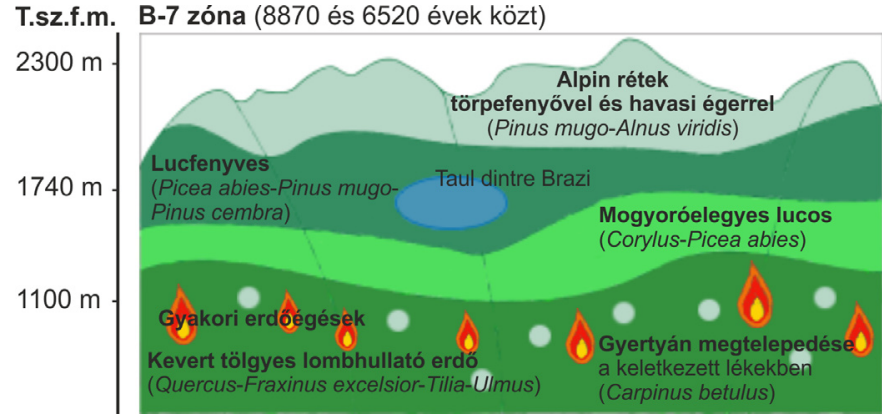

9. ábra: Alacsonyabb tengerszint feletti magasságban található kevert tölgyes erdóben gyakoribb erdôtüzek fordultak elő a klímaoszcilláció idején.

tin-hegységben, mint az alacsonyabb földrajzi szélességen elhelyezkedö, következésképpen melegebb klímájú Retyezátban.

A klímaoszcilláció ideje alatt a tó körül stabil állományt képező lucfenyves és törpefenyves zónában nem történt említést érdemlő változás. Ezzel szemben az alacsonyabb tengerszint feletti magasságokban a gyertyán hirtelen megjelenése a legszembetűnőbb a vizsgált időszak folyamán. A holocén korai szakaszára általában nem, vagy csak nagyon alacsony arányban jellemző gyertyán 8150 és 8100 évek között nagyobb százalékos előfordulást mutat. A pollen százalékos és akkumulációs ráta diagramok részletesebb elemzése alapján elmondható, hogy a gyertyán a lombhullató erdőkben található magas kőris rovására terjedt el, amiből arra következtethetünk, hogy a klímaoszcilláció ideje alatt bekövetkező változások az alacsonyabb tengerszint feletti magasságokban található erdők szerkezetében okoztak változásokat. A klímaoszcillációval egy időben több esetben, nagyobb akkumulációs rátájú, periodikusan visszatérő mikropernye csúcsot mutattunk ki. Ezeket összekapcsolva az erdőszerkezeti változásokkal, azt mondhatjuk, hogy az alacsonyabb tengerszint feletti magasságban elterülő erdők fajösszetételében bekövetkező változások összefüggésbe hozhatóak az epizodikus erdóégésekkel. A kevert tölgyes lombhullató erdőzónát alkotó fajok egy részében bekövetkező változásokból arra következtethetünk, hogy az erdőtüzek ebben a zónában jelentkeztek (9. ábra).

Az erdőégések hatására a zárt lombkoronával rendelkező kevert tölgyes lombhullató erdőben lékek keletkeztek. Egy újabb tanulmány szerint a periodikusan visszatérő erdőtüzek elősegíthetik a gyertyán megtelepedését olyan klimax erdőtársulásokban, melyekbe lékek hiányában a makroklíma miatt korábban nem versenyképes fajok kolonizálhatnak (Feurdean et al., 2012). A klímaoszcillációk a makroklíma időszakos változásához vezetnek, mely a 8200 éves klímaoszcilláció esetén kedvezett a gyertyánnak (úgy is mondhatjuk, hogy a klíma a gyertyán niche-ének megfelelő irányba tolódott el). Kárpátmedencei példával élve, ma a gyertyán a bükkös zónában erdőirtásokat követően mindig fontos szerepet játszik a beerdősülés kezdeti stádiumában (Standovár \& Kende- 
res, 2003), ezért feltételezhetö hogy az erdőtüzek hatására megjelenő lékekben 8200 év körül is sikeresen kolonizált.

A Retyezát-hegységben a klímaoszcilláció ideje alatt a pollen vizsgálataink alapján elmondható, hogy nyáron melegebb és tartósan csapadékmentes éghajlati feltételek uralkodtak (kontinentalitás fokozódása, nyári aszály). Ezt felerősíthette Európa középső területeinek egyébként is meleg és száraz nyári éghajlata a kora és közép holocénben, amit a nyári besugárzás maximuma okozott (Berger, Loutre, \& Laskar 1992). Télen a besugárzás minimuma miatt hideg éghajlati feltételek uralkodtak (Finsinger et al., 2006). Pollen és mikropernye vizsgálati eredményeink alapján tehát a 8200 éves klímaoszcilláció egy egyébként is kontinentális klímájú időszakában a kontinentalitás további fokozódásához vezetett a Retyezát-hegységben. Ezzel szemben az Alpokban Tinner és Lotter (2001) a klímaoszcilláció ideje alatt hüvösebb és csapadékosabb éghajlatot feltételeznek, míg egy másik tanulmányban (Ralska-Jasiewiczowa, Demske, \& van Geel, 1998) ez idő alatt hűvösebb és száraz éghajlati feltételeket mutattak ki. Feurdean (2005) kutatása alapján arra a következtetésre jutott, hogy inkább az utóbbi feltételezés tekinthető valósnak, mert ebben az időszakban az általa vizsgált területen csökkent a tölgy és a hárs pollenszázaléka, és ezzel egyidejűleg pedig a mogyoró pollen százalékának aránya megnövekedett. A lombhullató taxonok pollenszázalékának csökkenését Feurdean et al. (2008) pollen alapú klímarekonstrukciót alkalmazva a vegetációs periódusban érvényesülő alacsonyabb átlaghőmérsékletekkel indokolta, mely a mogyoró növekedése által jelzett szárazabb nyarak gyakoriságának növekedésével társult. Itt ugyanakkor fontos megjegyeznünk, hogy ma a mogyoró csak olyan atlantikus klímájú területeken fordul elő, ahol nyári aszály nem áll fenn (pl. Írország, Közép-Németország). A hegyvidéki pollendiagramok alapján készített klímarekonstrukciók minden esetben óvatossággal kezelendők, mert több vegetációzóna együttes változásait rögzítik, szemben a síkvidékekkel. A Feurdean et al. (2008) által rekonstruált alacsonyabb nyári középhőmérséklet ellentmond az általunk detektált erdőégéseknek, melyek meleg/száraz nyarak idején jellemzők. A pollen alapú klíma rekonstrukciók esetén gyakori jelenség hogy az éves és nyári középhőmérséklet rekonstrukciók csatolt választ adnak, azaz mindkét érték csökken, akkor is, ha csak a téli középhőmérséklet vagy a hozzáférhető vízmennyiség csökkent (Huntley 2012; Magyari et al., 2012). Az Alpokban és Lengyelországban a mogyoró tekintetében a Kárpátokban tapasztalt növekedéssel ellentétes irányú változást detektáltak a pollen diagramokban. Három tó üledékén végzett pollenanalitikai vizsgálatok eredményei (Tinner \& Lotter, 2001; Ralska-Jasiewiczowa et al., 1998) a 8200 éves klímaoszcilláció ideje alatt a mogyoró pollenszázalékának jelentős csökkenését mutatták. Mivel ezek a területek ma erős at- lanti klímahatás alatt állnak, a Kárpátokénál alacsonyabb nyári középhőmérséklet és magasabb nyári csapadék jellemzi őket, ezért itt a mogyoró csökkenése valószínüleg a vegetációs periódus hőösszegének csökkenésére vagy a téli középhőmérséklet erőteljes csökkenésére utal. Amennyiben a mogyoró pollenszázalékának csökkenését ezeken a területeken a vegetációs periódus hőmérsékletének csökkenése okozta, akkor arra következtethetünk, hogy az atlantikus és kontinentális területeken eltérő volt klímaváltozás: az atlanti területek nyári középhőmérsékletének csökkenése, a kontinentális területeken fokozódó nyári aszály érvényesült.

\subsection{Eredményeink összevetése további mód- szerek eredményeivel}

A 8200 éves klímaoszcilláció idején a Brazi-tó pollen diagramjában bekövetkezett változásokat összehasonlítottuk az üledéken végzett további vizsgálatok eredményeivel (szervesanyag-tartalom és biogén kova változásai, fontosabb diatóma fajok, az életformáikat és a tó vizének pH változásai - Buczkó et al., 2013) (10. ábra).

A szervesanyag-tartalom változásait nézve a 8000 és 9000 évek közt a szervesanyag-tartalom viszonylag magas, 50\% fölötti. A magas szervesanyag-tartalom a tó alacsony vízszintjére, valamint a lápzóna és a szárazföldi erdő magas biológiai produkciójára utal. Ebből arra következtethetünk, hogy a 8200 éves klímaoszcilláció egy meleg nyarú/vízdeficites időszakba ágyazódik a tó történetében. A lokális minimumok idején a tó felülete nagy valószínüséggel időszakosan nőtt, a szervesanyagtartalom csökkenéséhez a biogén kova (diatóma) produkció növekedése vezetett (10. ábra). 9000 és 8375 évek között a tóban sajátos diatómaflóra figyelhető meg, mely összefüggésbe hozható a tó alacsony vízállásával, és relatíve magas tavaszi, kora nyári hőmérsékletével. A perifitikus és bentikus fajok dominálnak, planktonikus fajok alig vannak, ami arra utal, hogy a tavat vastag lápzóna vette körül és a nyílt víztest mérete kicsi volt. A szürke színezéssel jelölt időszak a klímaoszcillációt jelöli. Megfigyelhető az Aulacoseira valida csúcsa 8150 évnél, ami egybeesik a gyertyán pollenszázalékának hirtelen növekedésével. Az Aulacoseira valida planktonikus, szélturbulenciát jelző faj, döntően olyan vizekben tud tartósan jelen lenni, ahol az erősen kovásodott váza a vízben lebegni tud. Nagyobb tömege miatt gyorsan kiülepedne, így a lebegéshez szükséges valamilyen fokú vízmozgás. A planktonikus diatómák virágzásának időszaka a jégolvadás idejére, tavaszra tehető a Retyezát-hegységben (Magyari et al., 2013; Buczkó et al., 2013). Az Aulacoseira valida csúcsa mindenképpen a tavaszi víztest méretének időszakos növekedésére utal 8150 évnél, ami erős szélhatással és feltehetően a tó felületi növekedésével párosult, mely magas téli és tavaszi csapadék eredményeként állhat elő. A mikropernye/pollen vizsgálati eredményekkel együttesen arra utal, hogy a Retyezátban 8200 


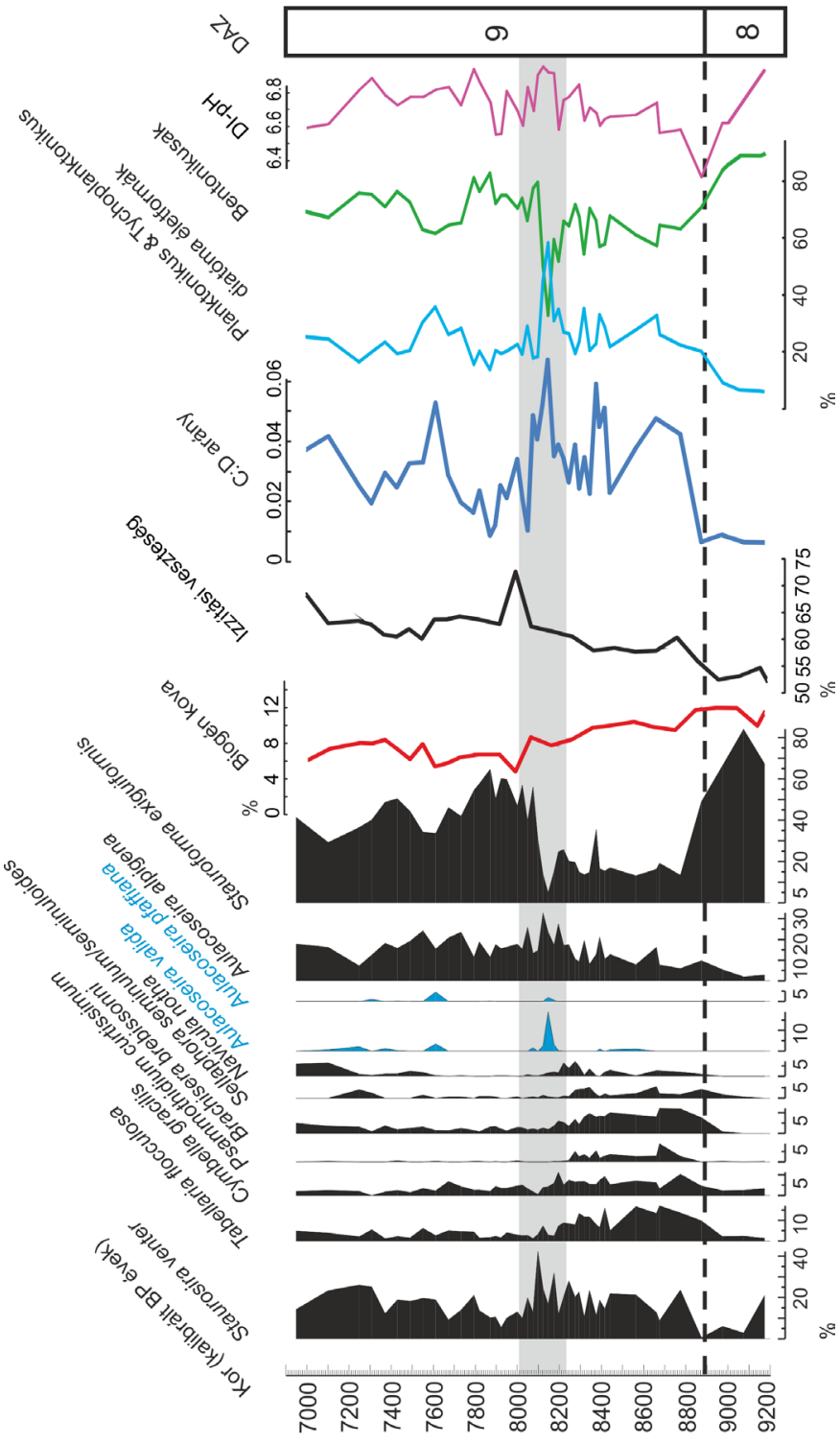

10. ábra: Más módszerek vizsgálati eredményei a $\mathbf{8 2 0 0}$ évvel ezelőtt bekövetkezett klímaoszcilláció idején (Buczkó et al., 2013 alapján).

év környékén a téli/tavaszi csapadék mennyisége nőtt, a nyári csapadék mennyisége viszont jelentősen csökkent, azaz erőteljes csapadékeloszlásbeli változás ment végbe. Ezek az eredmények egybevágnak a diatómák vázán végzett oxigénizotóp vizsgálati eredményekkel, melyek szintén a téli félév csapadékának növekedését jelzik ebben az időszakban (Magyari et al., 2013), ahol a szerző a téli félév csapadéknövekedését a pozitív észak-atlanti oszcillációs évek növekvő arányával hozza összefüggésbe (ekkor az azori magas nyomású öv és az izlandi alacsony nyomású öv közötti nyomáskülönbség kicsi).

\section{5. Összegzés}

Kutatásunk középpontja a Retyezát-hegység északi lejtőjén elhelyezkedő Brazi-tó, melynek fekvése különösnek tekinthető az éghajlati hatások érvényesülése miatt. Célunk annak a vizsgálata volt, hogy a kora holocénre jellemző rövid ideig tartó klímafluktuációk közül a 8200 évvel ezelött bekövetkezett klímaoszcilláció idején jelentkezett-e a vegetáció összetételében nagyobb arányú változás.

Eredményeink arra utalnak, hogy a Retyezát északi lejtőjének vegetációjában jelentős változások zajlottak a klímaoszcilláció ideje alatt (8300 és 8000 évek közt). A tó annak a csapadékosabb, kis párolgással jellemezhető zónának a déli határán fekszik, ahol a klímaoszcilláció ideje alatt Magny (2007) vizsgálatai szerint magasabb tóvízszint és így növekvő hozzáférhető vízmennyiség alakult ki. A Retyezátban vizsgálataink alapján a növénytakaróban bekövetkező jelentősebb változások leginkább az alacsonyabb tengerszint feletti magasságokat érintették. Az itt elhelyezkedő lombhullató erdőzónában fokozódott az erdőtüzek gyakorisága a klímaoszcilláció ideje alatt jelentkező magasabb nyári hőmérséklet és tartós csapadékhiány következtében, eredményeként a kontinentalitás és szezonalitás fokozódására következtethetünk. Az erdőtüzek periodikus visszatérése elősegítette az erdők felnyílását, mely a kialakuló lékekben a gyertyán megjelenésének, és későbbi elterjedésének biztosított teret.

Adatainkat együtt értelmezve az üledéken végzett diatóma, szervesanyag-tartalom és biogén szilikáttartalomvizsgálatok eredményeivel azt mondhatjuk, hogy a 8200 éves klímaoszcilláció a Retyezátban ellentétes változásokhoz vezetett a téli és nyári félévben: a téli félév hozzáférhető vízmennyisége egyértelműen nőtt, szemben a nyári félévben tapasztalt csökkenéssel. Összességében tehát erőteljes szezonalitásbeli eltolódás jellemezte a területet, a kontinentalitás mértékének erőteljes növekedésével.

Kutatásunk jelentősége a holocénre jellemző, rövid időszakokat felölelő klímaingadozások mechanizmusának pontosabb megértésében áll, hiszen az éghajlati feltételek módosulása jelentős változásokat eredményez a vegetáció összetételében. A 8200 évvel ezelőtt bekövetkezett klímaoszcilláció lehülésként jelentkezik ugyan, azonban nem vonatkozik a teljes évre, hanem csak a téli időszakra. A Retyezát-hegység alacsonyabb tengerszint feletti magasságában bekövetkező változások alapján következtethetünk a nyári hőmérséklet növekedésére és a tartósabb csapadékmentes időszakok érvényesülésére az alföldi és dombvidéki területeken. 


\section{Irodalomjegyzék}

Alley, R. B., Marotzke, J., Nordhaus, W. D., Overpeck, J. T., Peteet, D. M., Pielke, R. A., ... Wallace, J. M. (2003). Abrupt Climate Change. Science, 299(5615), 2005-2010. doi:10.1126/science. 1081056

Andersen, S. T. (1967). Tree-pollen rain in a mixed deciduous forest in South Jutland (Denmark). Review of Palaeobotany and Palynology, 3(1-4), 267-275. doi:10.1016/0034-6667(67)90059-0

Barber, D. C., Dyke, A., Hillaire-Marcel, C., Jennings, A. E., Andrews, J. T., Kerwin, M. W., ... Gagnon, J.-M. (1999). Nature, 400(6742), 344-348. doi:10.1038/22504

Bauer, E., Ganopolski, A., \& Montoya, M. (2004). Simulation of the cold climate event 8200 years ago by meltwater outburst from Lake Agassiz. Paleoceanography, 19(3), PA3014 doi:10.1029/2004pa001030

Bennett, K. D. (2007). Psimpoll 4.27 [Szoftver]. Letöltve: http://chrono.qub.ac.uk/psimpoll/psimpoll.html

Bennett, K. D., \& Willis, K. J. (2001). Pollen. In J. P. Smol, H. J. B. Birks \& W. M. Last (Eds.), Tracking Environmental Change Using Lake Sediments. Developments in Paleoenvironmental Research (Vol 3. pp. 5-32). Dordrecht: Springer Netherlands doi:10.1007/0-306-47668$\underline{12}$

Berger, A., Loutre, M. F., \& Laskar, J. (1992). Stability of the Astronomical Frequencies Over the Earth's History for Paleoclimate Studies. Science 255(5044), 560-566. doi:10.1126/science.255.5044.560

Birks, H. J. B., \& Gordon, A. D. (1985). Numerical methods in Quaternary pollen analysis. Academic Press: London.

Braun M., Hubay, K., Magyari E., Veres, D., Papp I., \& Bálint, M. (2013). Using linear discriminant analysis (LDA) of bulk lake sediment geochemical data to reconstruct lateglacial climate changes in the South Carpathian Mountains. Quaternary International, 293, 114-122. doi:10.1016/j.quaint.2012.03.025

Buczkó, K., Magyari, E., Hübener, T., Braun, M., Bálint, M., Tóth, M., \& Lotter, A. F. (2012). Responses of diatoms to the Younger Dryas climatic reversal in a South Carpathian mountain lake (Romania). Journal of Paleolimnology, 48(2), 417-431. doi:10.1007/s10933-0129618-1

Buczkó, K., Magyari, E. K., Braun, M., \& Bálint, M. (2013). Diatom-inferred lateglacial and Holocene climatic variability in the South Carpathian Mountains (Romania). Quaternary International, 293, 123-135. doi:10.1016/j.quaint.2012.04.042

Chytrý, M., Danihelka, J., Horsák, M., Kočí, M.,
Kubešová, S., Lososová, Z., ... Baisheva, E. Z. (2010). Modern analogues from the Southern Urals provide insights into biodiversity change in the early Holocene forests of Central Europe. Journal of Biogeography, 37(4), 767-780. doi:10.1111/j.1365-2699.2009.02256.x

Feurdean, A. (2005). Holocene forest dynamics in northwestern Romania. Holocene, 15(3), 435-446. doi:10.1191/0959683605hl803rp

Feurdean, A., Klotz, S., Mosbrugger, V., \& Wohlfarth, B. (2008). Pollen-based quantitative reconstructions of Holocene climate variability in NW Romania. Palaeogeography, Palaeoclimatology, Palaeoecology, 260(34), 494-504. doi:10.1016/j.palaeo.2007.12.014

Feurdean, A., Spessa, A., Magyari, E. K., Willis, K. J., Veres, D., \& Hickler, T. (2012). Trends in biomass burning in the Carpathian region over the last 15,000 years. Quaternary Science Reviews, 45, 111-125. doi:10.1016/ j.quascirev.2012.04.001

Finsinger, W., Tinner, W., van der Knaap, W. O., Ammann, B. (2006). The expansion of hazel (Corylus avellana L.) in the southern Alps: a key for understanding its early Holocene history in Europe? Quaternary Science Reviews, 25(5-6), 612-631. doi:10.1016/j.quascirev.2005.05.006

Finsinger, W., Kelly, R., Fevre, J., \& Magyari, E. K. (2014). A guide to screening charcoal peaks in macrocharcoal-area records for fire-episode reconstructions. The Holocene, 24(8), 1002-1008. doi:10.1177/0959683 614534737

Haas, J. N., Richoz, I., Tinner, W., \& Wick, L. (1998). Synchronous Holocene climatic oscillations recorded on the Swiss Plateau and at timberline in the Alps. The Holocene, 8(3), 301-309. doi:10.1191/095968398675491173

Huntley, B. (2012). Reconstructing palaeoclimates from biological proxies: Some often overlooked sources of uncertainty. Quaternary Science Reviews, 31, 1-16. doi:10.1016/j.quascirev.2011.11.006

Joerin, U. E., Stocker, T. F., \& Schlüchter, C. (2006). Multicentury glacier fluctuations in the Swiss Alps during the Holocene. Holocene, 16(5), 697-704. doi:10.1191/ 0959683606h1964rp

Kofler, W., Krapf, V., Oberhuber, W., \& Bortenschlager, S. (2005). Vegetation responses to the $8200 \mathrm{cal}$. BP cold event and to long-term climatic changes in the Eastern Alps: possible influence of solar activity and North Atlantic freshwater pulses. Holocene, 15(6), 779-788. doi:10.1191/0959683605hl852ft

Magny, M., Bégeot, C., Guiot, J., Marguet, A., \& Billaud, Y. (2003). Reconstruction and palaeoclimatic interpretation of mid-Holocene vegetation and lake-level changes at Saint-Jorioz, Lake Annecy, French Pre-Alps. The Holocene, 13(2), 265-275. doi:10.1191/0959683603hl612rp 
Magny, M. (2007). Lake level studies: West-Central Europe. In S. A. Elias (Ed.), Encyclopedia of Quaternary Science (pp. 1389-1399). Amsterdam: Elsevier. doi:10.1016/B0-44-452747-8/00169-1

Magny, M., Vannière, B., de Beaulieu, J.-L., Bégeot, C., Heiri, O., Millet, L., ... Walter-Simonnet, A.-V. (2007). Early-Holocene climatic oscillations recorded by lakelevel fluctuations in west-central Europe and in central Italy. Quaternary Science Reviews, 26(15-16), 19511964. doi:10.1016/j.quascirev.2006.04.013

Magyari, E. K., Braun, M., Buczkó, K., Kern, Z., László, P., Hubay, K., \& Bálint, M. (2009). Radiocarbon chronology of glacial lake sediments in the Retezat Mts (South Carpathians, Romania): a window to Late Glacial and Holocene climatic and paleoenvironmental changes. Central European Geology, 52(3-4), 225-248. doi:10.1556/ ceugeol.52.2009.3-4.2

Magyari, E. K., Major, Á., Bálint, M., Nédli, J., Braun, M., Rácz, I., \& Parducci, L. (2011). Population dynamics and genetic changes of Picea abies in the South Carpathians revealed by pollen and ancient DNA analyses. $B M C$ Evolutionary Biology, 11(1), 66. doi:10.1186/1471-2148$\underline{11-66}$

Magyari, E. K., Jakab, G., Bálint, M., Kern, Z., Buczkó, K., \& Braun, M. (2012). Rapid vegetation response to Lateglacial and early Holocene climatic fluctuation in the South Carpathian Mountains (Romania). Quaternary Science Reviews, 35, 116-130. doi:10.1016/ j.quascirev.2012.01.006

Magyari, E. K., Demény, A., Buczkó, K., Kern, Z., Vennemann, T., Fórizs, I., ... Veres, D. (2013). A 13,600year diatom oxygen isotope record from the South Carpathians (Romania): Reflection of winter conditions and possible links with North Atlantic circulation changes. Quaternary International, 293, 136-149. doi:10.1016/ j.quaint.2012.05.042

Magyari E. K., Peyron, O., Tóth M., Heiri, O., \& Lotter, A. F. (2012). Pollen- and chironomid-based reconstruction of late glacial summer temperatures in the southern Carpathians (Romania): conflicting results and supporting independent proxies [Abstract]. In W. Z. Hoek (Ed.), INTIMATE INTegrating Ice core, Marine and TErrestrial records: Climate and environmental change from 60,000-8000 years ago (p. 56). Letöltve: http://costes0907.geoenvi.org/attachments/article/77/ABSTRACT S\%20VOLUME\%20final.pdf

Maher, L. J. (1981). Statistics for microfossil concentration measurements employing samples spiked with marker grains. Review of Palaeobotany and Palynology, 32(2-3), 153-191. doi:10.1016/0034-6667(81)90002-6

Mayewski, P.A., Rohling, E. E., Curt Stager, J., Karlén, W.,
Maasch, K. A., David Meeker, L., ... Steig, E. J. (2004). Holocene climate variability. Quaternary Research, 62(3), 243-255. doi:10.1016/j.yqres.2004.07.001

Ortu, E., Brewer, S., \& Peyron, O. (2006). Pollen-inferred palaeoclimate reconstructions in mountain areas: problems and perspectives. Journal of Quaternary Science, 21(6), 615-627. doi:10.1002/jqs.998

Ortu, E., David, F., \& Peyron, O. (2009). Pollen-inferred palaeoclimate reconstruction in the Alps during the Lateglacial and the early Holocene: how to estimate the effect of elevation and local parameters. Journal of Quaternary Science, 25(5), 651-661. doi:10.1002/jqs.1335

Peteet, D. (2000). Sensitivity and rapidity of vegetational response to abrupt climate change. Proceedings of the National Academy of Sciences, 97(4), 1359-1361. doi:10.1073/pnas.97.4.1359

Rahmstorf, S. (2000) The Thermohaline Ocean Circulation: A System with Dangerous Thresholds? Climatic Change, 46(3), 247-256. doi:10.1023/a:1005648404783

Ralska-Jasiewiczowa, M., Demske, D., van Geel, B. (1998). Late-glacial vegetation history recorded in the Lake Gosciaz sediments. In T. Goslar, T. Madeyska, M. Ralska-Jasiewiczowa \& L. Starkel (Eds.), Lake Gosciaz, Central Poland (pp. 128-143). W. Szafer Institute of Botany, Polish Academy of Sciences: Krakow.

Rasmussen, S. O., Andersen, K. K., Svensson, A. M., Steffensen, J. P., Vinther, B. M., Clausen, H. B., ... Ruth, U. (2006). A new Greenland ice core chronology for the last glacial termination. Journal of Geophysical Research, 111(D6). doi:10.1029/2005jd006079

Rasmussen, S. O., Vinther, B. M., Clausen, H. B., \& Andersen, K. K. (2007). Early Holocene climate oscillations recorded in three Greenland ice cores. Quaternary Science Reviews, 26(15-16), 1907-1914. doi:10.1016/ j.quascirev.2007.06.015

Renssen, H., \& Isarin, R. F. B. (2001). The two major warming phases of the last deglaciation at $\sim 14.7$ and $\sim 11.5 \mathrm{ka}$ cal BP in Europe: climate reconstructions and AGCM experiments. Global and Planetary Change, 30(1-2), 117-153. doi:10.1016/s0921-8181(01)00082-0

Seppä, H. (2007). Pollen analysis, principles. In S. A. Elias (Ed.), Encyclopedia of Quaternary Science (pp. 2486-2497). Amsterdam: Elsevier. doi:10.1016/b0-44452747-8/00175-7

Standovár, T., \& Kenderes, K. (2003). A review on natural stand dynamics in beechwoods of East Central Europe. Applied Ecology and Environmental Research, 1(1-2), 19-46. doi:10.15666/aeer/01019046

Stocker, T. F. (2000). Past and future reorganizations in the climate system. Quaternary Science Reviews, 19(1- 
5), 301-319. doi:10.1016/s0277-3791(99)00067-0

Tanţău, I., Feurdean, A., de Beaulieu, J.-L., Reille, M., \& Fărcaş, S. (2011). Holocene vegetation history in the upper forest belt of the Eastern Romanian Carpathians. Palaeogeography, Palaeoclimatology, Palaeoecology, 309(3-4), 281-290. doi:10.1016/j.palaeo.2011.06.011

Teller, J. T., Leverington, D. W., \& Mann, J. D. (2002). Freshwater outbursts to the oceans from glacial Lake Agassiz and their role in climate change during the last deglaciation. Quaternary Science Reviews, 21(8-9), 879887. doi:10.1016/s0277-3791(01)00145-7

Thomas, E. R., Wolff, E. W., Mulvaney, R., Steffensen, J. P., Johnsen, S. J., Arrowsmith, C., ... Popp, T. (2007). The $8.2 \mathrm{ka}$ event from Greenland ice cores. Quaternary Science Reviews, 26(1-2), 70-81. doi:10.1016/ j.quascirev.2006.07.017

Tinner, W., \& Lotter, A. F. (2001). Central European vegetation response to abrupt climate change at 8.2 ka. Geology, 29(6), 551-554. doi.10.1130/00917613(2001)029<0551:cevrta $>2.0$. co; 2

Tóth, M., Magyari, E. K., Brooks, S. J., Braun, M., Buczkó, K., Bálint, M., \& Heiri, O. (2012). A chironomid-based reconstruction of late glacial summer temperatures in the southern Carpathians (Romania). Quaternary Research, 77(1), 122-131. doi:10.1016/j.yqres.2011.09.005

Valsecchi, V., Carraro, G., Conedera, M., \& Tinner, W. (2010). Late-Holocene vegetation and land-use dynamics in the Southern Alps (Switzerland) as a basis for nature protection and forest management. The Holocene, 20(4), 483-495. doi:10.1177/0959683609355178

Veski, S., Seppä, H., \& Ojala, A. E. K. (2004). Cold event at 8200 yr B.P. recorded in annually laminated lake sediments in eastern Europe. Geology, 32(8), 681. doi: $10.1130 / \mathrm{g} 20683.1$

Vinther, B. M., Clausen, H. B., Johnsen, S. J., Rasmussen, S. O., Andersen, K. K., Buchardt, S. L., ... Heinemeier, J. (2006). A synchronized dating of three Greenland ice cores throughout the Holocene. Journal of Geophysical Research, 111(D13). doi:10.1029/2005jd006921
Walker, M. (2005). Quaternary Dating Methods. John Wiley \& Sons Ltd: Chichester.

Wanner, H., Beer, J., Bütikofer, J., Crowley, T. J., Cubasch, U., Flückiger, J., ... Widmann, M. (2008). Mid- to Late Holocene climate change: an overview. Quaternary Science Reviews, 27(19-20), 1791-1828. doi:10.1016/ j.quascirev.2008.06.013

Weninger, B., Alram-Stern, E., Bauer, E., Clare, L., Danzeglocke, U., Jöris, O., ... van Andel, T. (2006). Climate forcing due to the $8200 \mathrm{cal} \mathrm{yr} \mathrm{BP}$ event observed at Early Neolithic sites in the eastern Mediterranean. Quaternary Research, 66(3), 401-420. doi:10.1016/ j.yqres.2006.06.009

Weninger, B., Clare, L., Rohling, E., Bar-Yosef, O., Böhner, U., Budja, M., ... Zielhofer, C. (2009). The Impact of Rapid Climate Change on Prehistoric Societies during the Holocene in the Eastern Mediterranean. Documenta Praehistorica, 36(0), 7. doi:10.4312/dp.36.2

Wick, L. (2000). Vegetational response to climatic changes recorded in Swiss Late Glacial lake sediments. Palaeogeography, Palaeoclimatology, Palaeoecology, 159(3-4), 231-250. doi:10.1016/s0031-0182(00)00087$\underline{0}$

Wohlfarth, B., Hannon, G., Feurdean, A., Ghergari, L., Onac, B. P., \& Possnert, G. (2001). Reconstruction of climatic and environmental changes in NW Romania during the early part of the last deglaciation $(\sim 15,000-13,600 \mathrm{cal}$ yr BP). Quaternary Science Reviews, 20(18), 1897-1914. doi:10.1016/s0277-3791(01)00014-2

Young, N. E., Briner, J. P., Rood, D. H., \& Finkel, R. C. (2012). Glacier Extent During the Younger Dryas and 8.2-ka Event on Baffin Island, Arctic Canada. Science, 337(6100), 1330-1333. doi:10.1126/science.1222759 